\title{
Loss of H3K4 methylation destabilizes gene expression patterns and physiological functions in adult murine cardiomyocytes
}

\author{
Adam B. Stein, ${ }^{1}$ Thomas A. Jones, ${ }^{1}$ Todd J. Herron, ${ }^{1}$ Sanjeevkumar R. Patel, ${ }^{1}$ \\ Sharlene M. Day, ${ }^{1}$ Sami F. Noujaim, ${ }^{1}$ Michelle L. Milstein, ${ }^{1}$ Matthew Klos, ${ }^{1}$ \\ Philip B. Furspan, ${ }^{1}$ José Jalife, ${ }^{1}$ and Gregory R. Dressler ${ }^{2}$ \\ ${ }^{1}$ Department of Internal Medicine and ${ }^{2}$ Department of Pathology, University of Michigan, Ann Arbor, Michigan, USA.
}

\begin{abstract}
Histone $\mathrm{H} 3$ lysine 4 (H3K4me) methyltransferases and their cofactors are essential for embryonic development and the establishment of gene expression patterns in a cell-specific and heritable manner. However, the importance of such epigenetic marks in maintaining gene expression in adults and in initiating human disease is unclear. Here, we addressed this question using a mouse model in which we could inducibly ablate PAX interacting (with transcription-activation domain) protein 1 (PTIP), a key component of the H3K4me complex, in cardiac cells. Reducing $\mathrm{H} 3 \mathrm{~K} 4 \mathrm{me} 3$ marks in differentiated cardiomyocytes was sufficient to alter gene expression profiles. One gene regulated by $\mathrm{H} 3 \mathrm{~K} 4 \mathrm{me} 3$ was $\mathrm{Kv}$ channel-interacting protein 2 (Kcnip2), which regulates a cardiac repolarization current that is downregulated in heart failure and functions in arrhythmogenesis. This regulation led to a decreased sodium current and action potential upstroke velocity and significantly prolonged action potential duration (APD). The prolonged APD augmented intracellular calcium and in vivo systolic heart function. Treatment with isoproterenol and caffeine in this mouse model resulted in the generation of premature ventricular beats, a harbinger of lethal ventricular arrhythmias. These results suggest that the maintenance of $\mathrm{H} 3 \mathrm{~K} 4 \mathrm{me} 3$ marks is necessary for the stability of a transcriptional program in differentiated cells and point to an essential function for $\mathrm{H} 3 \mathrm{~K} 4 \mathrm{me} 3$ epigenetic marks in cellular homeostasis.
\end{abstract}

\section{Introduction}

Histone methylation is a well-conserved posttranslational modification that can be associated with active or repressed genes, depending on which specific lysine or arginine residues are methylated $(1,2)$. Histone $\mathrm{H} 3$ lysine $4(\mathrm{H} 3 \mathrm{~K} 4)$ methylation, the focus of this study, generally correlates with transcriptional expression (2). High levels of $\mathrm{H} 3 \mathrm{~K} 4$ trimethylation ( $\mathrm{H} 3 \mathrm{~K} 4 \mathrm{me} 3)$ are associated with the $5^{\prime}$ region of nearly all active genes and correlate with polymerase II occupancy, transcription rates, and histone acetylation (3).

H3K4 methylation marks are imparted by the trithorax group ( $\mathrm{TrG}$ ) of histone methyltransferase complexes that were originally identified as regulators of body patterning in Drosophila. In mammals, the TrG family includes the related myeloid/lymphoid or mixed lineage leukemia proteins 1-4 (KMT2A-KMT2D, also known as MLL1-MLL4). Individual KMT2s and their cofactors are essential for embryonic development and the establishment of correct gene expression patterns, presumably by demarcating the active and accessible regions of the genome in a cell-specific and heritable manner (4). Although these complexes and the H3K4me marks they impart are important in development, little is known about their importance in maintaining gene expression profiles in fully differentiated tissues. Furthermore, recent work suggests that there is an association between altered $\mathrm{H} 3 \mathrm{~K} 4 \mathrm{me} 3$ marks and human and rodent cardiac disease (5). Yet, it is unclear whether such alterations in histone methylation are the cause or the result of the disease and what aspects of cardiac homeostasis are regulated by $\mathrm{H} 3 \mathrm{~K} 4 \mathrm{me} 3$ marks.

The cardiac repolarization $\left(\mathrm{I}_{\mathrm{to}}\right)$ gradient that regulates phase $\mathrm{I}$ of the cardiac action potential via potassium influx plays an important role

Conflict of interest: The authors have declared that no conflict of interest exists. Citation for this article: J Clin Invest. 2011;121(7):2641-2650. doi:10.1172/JCI44641. in the synchronized repolarization wave. Disruption of this current promotes cardiac arrhythmias, which are a leading cause of death in patients with heart failure and cardiomyopathy (6). $\mathrm{I}_{\mathrm{to}}$ is downregulated in diseased myocardium, and altered repolarization gradients are associated with ventricular tachycardia (7). $\mathrm{I}_{\text {to }}$ is regulated by the $\alpha$ subunits Kend 2 and $K c n d 3$, in association with $\beta$ subunits, such as Kv channel-interacting protein 2 (Kcnip2). Kcnip2 is downregulated in human models of heart failure (8), and targeted disruption of Kcnip2 eliminates the fast $\mathrm{I}_{\text {to }}$ current and increases susceptibility to ventricular tachycardia in murine ventricular cells (9). Despite the fact that the repolarization current is altered in disease states and plays a critical role in regulating the electrophysiological phenotype and arrhythmogenesis, little is known about the transcriptional regulation of the components that make up these channels.

In this report, we used a cardiac-specific, tamoxifen-inducible Cre driver to delete the PAX interacting (with transcription-activation domain) protein 1 (PTIP) protein, an essential cofactor for $\mathrm{H} 3 \mathrm{~K} 4 \mathrm{me}$ by KMT2C/D, to ask whether $\mathrm{H} 3 \mathrm{~K} 4$ me marks are important in maintaining gene expression profiles in a fully differentiated, nondividing cell type. PTIP is encoded by the Paxip1 gene and is essential for embryonic development in mice $(10,11)$ and flies $(12)$. As a critical component of the KMT2C/D complex $(11,13,14)$, loss of PTIP leads to reduced levels of $\mathrm{H} 3 \mathrm{~K} 4 \mathrm{me} 3$ in whole embryos (11), embryonic stem cells (15), and in Drosophila larvae (12). However, the function of these KMT2 complexes in adult tissue had not been addressed. Adult cardiomyocytes were used as a model cell type because they are generally nondividing, terminally differentiated cell types, represent approximately $50 \%$ of the total heart cell population, and have well-characterized, inducible Cre driver strains (16). Temporal and tissue-specific deletion of PTIP reduces $\mathrm{H} 3 \mathrm{~K} 4 \mathrm{me}$ and alters the transcriptional program in cardiomyocytes. This decreases Kcnip2 gene 
A
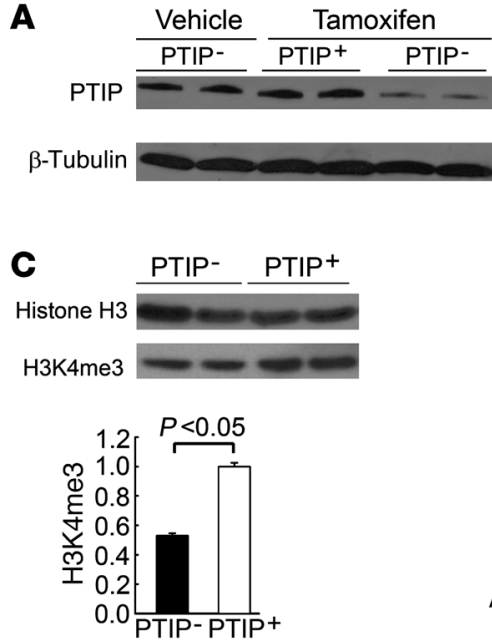

Figure 1

Cardiac-specific PTIP deletion affects H3K4me in mice. (A) PTIP protein expression $(140 \mathrm{kDa})$ was markedly decreased in the PTIP- mice injected with tamoxifen as compared with that in the vehicle-injected $\mathrm{PTIP}^{-}$and tamoxifen-injected PTIP+ mice. LV tissue was harvested 30 days after tamoxifen or vehicle injection, and immunoblotting was performed using chicken anti-PTIP (anti-PTIP) normalized to mouse anti- $\beta$-tubulin. (B) PTIP- $(n=3)$ and $\mathrm{PTIP}^{+}$mice $(n=3 /$ group) were injected with tamoxifen at 8 weeks of age. Thirty days later, LV tissue was harvested, mRNA was isolated, and QPCR was performed for PTIP and normalized to GAPDH using TaqMan primers. Data are mean \pm SEM. * $P<0.05$ versus PTIP-. (C) Eight-week-old PTIP- $(n=5)$ and $\mathrm{PTIP}^{+}(n=3)$ mice were injected with tamoxifen. Eight months later immunoblotting for $\mathrm{H} 3 \mathrm{~K} 4 \mathrm{me} 3$ and histone $\mathrm{H} 3$ (top) was performed from whole heart chromatin. Immunoblot data were quantified by normalizing H3K4me3 levels to H3 (bottom). Data are mean \pm SEM. (D) Whole heart tissue from PTIP+ mice was harvested and prepped for chromatin. IP was performed on $20 \mu \mathrm{g}$ chromatin using chicken anti-PTIP and chicken $\lg Y$ (control). IP samples were then denatured in SDS, loaded into a $6 \%$ SDS gel, and probed with chicken anti-PTIP and rabbit anti-RbbP5 (Bethyl). In the sample immunoprecipitated with chicken anti-PTIP (right lane), a 140-kDa band, consistent with PTIP, and a 70-kDa band, consistent with RbBP5, were detected. These bands were not detected in the sample immunoprecipitated with chicken IgY (middle lane).

expression and attenuates both $\mathrm{I}_{\mathrm{to}}$ and the sodium current $\left(\mathrm{I}_{\mathrm{Na}}\right)$. PTIP deletion also prolongs the action potential duration (APD) resulting in increased L-type calcium current $\left(\mathrm{I}_{\mathrm{C}, \mathrm{L}} \mathrm{L}\right)$ which leads to elevated intracellular calcium $\left[\mathrm{Ca}^{2+}\right]_{\mathrm{i}}$ and augments myocyte contractility in vivo and in vitro. Furthermore, PTIP mutant cardiomyocytes show a prolonged $\mathrm{PR}$ interval and are more sensitive to premature ventricular complexes (PVCs) upon stimulation, suggesting both a conduction defect and greater susceptibility to calcium-based ventricular arrhythmias. This study demonstrates a critical role of H3K4me marks in maintaining cellular homeostasis in fully differentiated tissue and suggests that epigenetic changes may underlie clinically relevant cardiac disease phenotypes.

\section{Results}

Generation of an inducible, cardiac-specific PTIP-null mouse. In order to delete the PTIP protein in cardiomyocytes, mice were bred to generate the tamoxifen-inducible Paxip1 deletion strains. Using a floxed $(f l)$, a null (-), and a wild-type (+) Paxip1 allele (11), the Cre-modified estrogen receptor transgene, driven by the cardiac-specific $\alpha$ myosin heavy chain promoter $\left(\alpha M H C^{\mathrm{MCM}}\right)$, was crossed into the Paxip $1^{1 /+}$ or Paxip $1^{f /-}$ genetic background to generate $\alpha M H C^{M C M}$ Paxip $1^{f / /}$ and

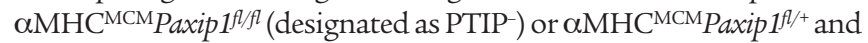
$\alpha \mathrm{MHC}^{\mathrm{MCM}}$ Paxip $1^{+/+}$(designated as PTIP $\mathrm{P}^{+}$) control mice. Thirty days after tamoxifen injection in 8-week-old mice, there was a marked decrease in steady-state PTIP protein levels in the tamoxifen-injected PTIP- mice as compared with that in the vehicle-injected PTIP- and the tamoxifen-injected PTIP+ mice (Figure 1A). After tamoxifen injection, PTIP- mice also have a 7- to 8-fold decrease in PTIP mRNA when compared with that in PTIP+ mice (Figure 1B).

PTIP is part of a histone methyltransferase complex that regulates histone methylation. To assess whether PTIP protein affects H3K4me in ventricular whole heart samples, we examined levels of H3K4me3 by quantitative Western blotting (Figure 1C). Compared with total amounts of histone $\mathrm{H} 3$, levels of $\mathrm{H} 3 \mathrm{~K} 4 \mathrm{me} 3$ were reduced to approximately $53 \%$ of controls. We prepared chromatin from control hearts for immunoprecipitation with anti-PTIP antibodies to examine protein-protein interactions directly on DNA. After reverse-crosslinking, proteins were separated on SDS/PAGE gels and probed for RbBP5 (Figure 1D), a component of the KMT2C/D complex (11), to show that PTIP is part of the H3K4me complex in whole heart tissue.

Histone methylation regulates gene expression. We next determined whether PTIP deletion and reduction in H3K4me3 was sufficient to alter gene expression profiles in the adult heart. Total RNA was isolated from cardiac tissue 30 days after tamoxifen injection from $\operatorname{PTIP}^{-}(n=3)$ and $\operatorname{PTIP}^{+}(n=3)$ mice. The RNAs were analyzed by Affymetrix microarrays to identify changes in gene expression patterns. A total of 221 genes were significantly, altered with $60 \%$ of them showing a decrease after PTIP deletion (Supplemental Table 1; supplemental material available online with this article; doi:10.1172/JCI44641DS1). These results are consistent with the hypothesis that the PTIP/KMT2C/D complex imparts H3K4me3 marks that are associated with active gene expression, at least within a subset of genes. Differential gene expression was confirmed by qPCR for selected genes (Figure 2A). Gene expression analysis was also performed on hearts from mice 8 months after tamoxifen injection (Figure 2B). Many genes that showed a decrease in expression at 1 month continued to exhibit a significant decrease 8 months after tamoxifen. In order to demonstrate that the attenuation in Kcnip2 was due to PTIP deletion and not due to genetic background or the injection of tamoxifen, Kcnip2 gene expression by qPCR was measured in Paxip $1^{f / /+}$ and Paxip1 $1^{f / / f}$ mice, with and without the $\alpha \mathrm{MHC}{ }^{\mathrm{MCM}}$ transgene and with and without tamoxifen (Supplemental Figure 1).

Gene-specific evidence that PTIP and H3K4me regulate gene expression in differentiated tissue. We next sought to demonstrate that PTIP deletion alters $\mathrm{H} 3 \mathrm{~K} 4 \mathrm{me} 3$ marks at a specific target gene promoter region in the heart. Thus, we performed ChIP assays using antibodies to $\mathrm{H} 3 \mathrm{~K} 4 \mathrm{me} 3$ to assess the methylation status at the $5^{\prime}$ regulatory region of the Kcnip2 gene (Figure 3A). The Kcnip2 gene was selected as a target partly because Kcnip 2 levels were reduced approximately 5 and 10 fold at 1 and 8 months, respectively, after PTIP deletion. In heart chromatin from $\mathrm{PTIP}^{+}$mice, H3K4me3 marks were enriched substantially at a DNA region -100 bp relative to the translation start site. A moderate enrichment in $\mathrm{H} 3 \mathrm{~K} 4 \mathrm{me} 3$ marks was seen at +100 bp relative to the first ATG, and little enrichment was observed at $-500 \mathrm{bp}$. In comparison, the $\mathrm{H} 3 \mathrm{~K} 4 \mathrm{me} 3$ enrichment at $-100 \mathrm{bp}$ and +100 bp was significantly attenuated in the heart chromatin from the PTIP- group. These results show that PTIP deletion does indeed 
A

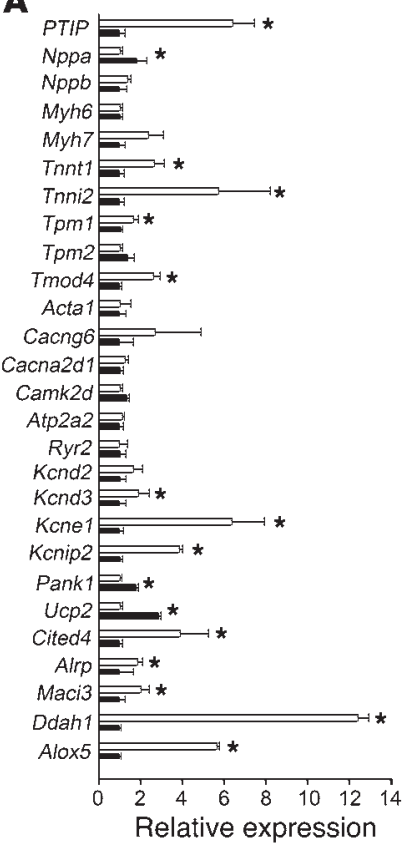

B

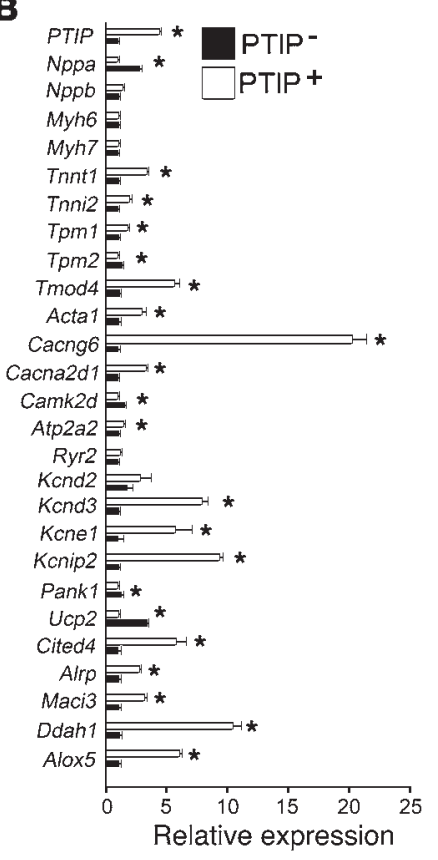

result in an alteration in $\mathrm{H} 3 \mathrm{~K} 4 \mathrm{me} 3$ marks at the $5^{\prime}$ regulatory region of the Kcnip2 gene. Next, we examined PTIP and RbBP5 localization to the $5^{\prime}$ regulatory region of the Kcnip2 gene (Figure 3A). In chromatin from PTIP+ hearts, both PTIP and RbBP5 were enriched at a DNA region -500 bp relative to the first Kcnip2 ATG. This enrichment was not observed at DNA regions $-100 \mathrm{bp}$ and $+100 \mathrm{bp}$ relative to the first ATG. However, in chromatin from PTIP- hearts, the PTIP and RbBP5 enrichment observed at -500 bp in PTIP $^{+}$mice was significantly reduced. No differences in PTIP and RbBP5 enrichment were observed between heart chromatin from PTIP ${ }^{+}$and PTIP- mice at -100 and +100 bp relative to the first ATG, as these levels were closer to background. Thus, we propose that the decrease in Kcnip2 transcript expression is a direct result of PTIP deletion and the inability of PTIP- mice to maintain a KMT2 complex and H3K4me3 marks at the $5^{\prime}$ regulatory region of the Kcnip2 gene (Figure 3B). As a negative control, we performed ChIP assays for H3K4me3 marks at the $5^{\prime}$ regulatory region of the $N p p b$ gene, a gene that shows no change in mRNA expression in PTIP- mice as compared with that in PTIP ${ }^{+}$mice (Supplemental Figure 2). We observed no changes in H3K 4 me3 enrichment at the $5^{\prime}$ regulatory region of the Nppb gene in PTIP- mice when compared with that in PTIP ${ }^{+}$mice. These results provide mechanistic evidence that maintaining histone methylation marks is critical for maintaining stable gene expression profiles in a fully differentiated, nondividing cell type.

Kcnip2, Kcnd2, and Kcnd3 protein expression. To determine whether mRNA profiles correspond to protein levels, hearts were harvested from PTIP- $^{-}$and PTIP $^{+}$mice 4 weeks after tamoxifen injection, and LVs were prepped for immunoblotting with anti-Kcnip2, anti-Kcnd2, and anti-Kend 3 antibodies (Figure 4A). These data reveal that in PTIP- mice there was a marked decrease in Kcnip2 protein as compared with that in $\mathrm{PTIP}^{+}$mice. Blotting for Kcnd 3 and Kcnd 2 revealed no significant difference in protein expression in $\mathrm{PTIP}^{+}$and PTIP- mice, despite the fact that Kcnd3 mRNA levels were significantly different in PTIP- mice as compared with those in PTIP+ $^{+}$mice.

\section{Figure 2}

Gene expression data in $\mathrm{PTIP}^{-}$and $\mathrm{PTIP}^{+}$mice. (A) Eight-week-old $\mathrm{PTIP}^{-}(n=3-5)$ and $\mathrm{PTIP}^{+}$mice $(n=3-5)$ were injected with tamoxifen for 5 days. Thirty days later, LV tissue was harvested, and qPCR was performed using TaqMan probes for the listed genes normalized to GAPDH. (B) Eight-week-old PTIP- $(n=5)$ and PTIP+ mice $(n=5)$ were injected with tamoxifen for 5 days. Eight months later, LV tissue was harvested, and qPCR was performed using TaqMan probes for the listed genes normalized to GAPDH. ${ }^{*} P<0.05$ versus PTIP-. All data are mean \pm SD.

EKG and action potential measurements. To investigate the significance of H3K4me marks in the heart, we studied the impact that PTIP deletion and the attenuation of Kcnip2 gene expression had on the electrophysiological phenotype. Initially, EKGs were obtained from PTIP ${ }^{+}$ and PTIP- mice 4 weeks after tamoxifen injection. As shown in Figure 4B, PTIP- mice had a marked and easily identified depression of the $\mathrm{ST}$ segment as compared with $\mathrm{PTIP}^{+}$mice. In addition, analysis of the EKG also revealed a significant increase in the PR interval in PTIPmice $(n=6)$ as compared with that in $\mathrm{PTIP}^{+}$mice $(n=6)(36.9 \pm 2.6$ ms. vs. $31.6 \pm 4.0$ ms., respectively; $P<0.05$ ). There were no significant differences in the heart rate of PTIP- mice when compared with that of PTIP ${ }^{+}$mice ( $666 \pm 20$ bpm vs. $661 \pm 28$ bpm, respectively). Next, LV apical myocytes were isolated from PTIP $^{+}$and PTIP- mice, and action potentials were recorded. As shown in Figure 4, C and D, the action potential profile was appreciably different in the PTIP- mice as compared with that in $\mathrm{PTIP}^{+}$mice. Objective measurements of the APD presented in Figure 4, E and F, demonstrated that PTIP- mice had a significantly longer APD, at $30 \%$ and $90 \%$ repolarization. The resting membrane potential (RMP) was also significantly higher in PTIP- mice $(N=4, n=10)$ as compared with that in $\mathrm{PTIP}^{+}$mice $(N=4$, $n=15)(-69.95 \pm 1.2 \mathrm{mV}$ vs. $-73.55 \pm 0.71 \mathrm{mV} ; P<0.05)$.

PTIP- mice have reduced $I_{N a}$. As shown above, EKG data revealed that there was a significant increase in the PR interval in PTIPmice as compared with that in $\mathrm{PTIP}^{+}$mice, which might have indicated that PTIP- hearts had a conduction defect in the His-Purkinje system. Furthermore, analysis of ventricular action potentials revealed a decrease in maximum upstroke velocity $(\mathrm{dV} / \mathrm{dt}$ ) (Figure $5 \mathrm{~A})$. Taken together, these results suggested that there may be a decrease in the sodium inward current $\left(\mathrm{I}_{\mathrm{Na}}\right)$ responsible for phase 0 of the cardiac action potential. Accordingly, we measured $\mathrm{I}_{\mathrm{Na}}$ in $\mathrm{LV}$ apical myocytes in PTIP $^{+}$and PTIP- mice. As shown in Figure 5B, PTIP deletion resulted in attenuated $\mathrm{I}_{\mathrm{Na}}$ in PTIP- hearts as compared with that in $\mathrm{PTIP}^{+}$hearts.

$I_{t o}$ is reduced in PTIP- mice. To determine whether H3K4me marks regulate $\mathrm{I}_{\text {to }}$, myocytes were isolated from the apex of $\mathrm{PTIP}^{-}$and PTIP $^{+}$mice, and $\mathrm{I}_{\text {to }}$ currents were measured in the presence of tetrodotoxin (TTX). Figure $6 \mathrm{~A}$ shows representative $\mathrm{I}_{\text {to }}$ recordings from PTIP $^{+}$and PTIP- mice. Figure $6 \mathrm{~B}$ displays peak $\mathrm{I}_{\text {to }}$ amplitudes as a function of test pulse; PTIP deletion resulted in a significant attenuation of $\mathrm{I}_{\text {to }}$ in $\mathrm{LV}$ apical myocytes.

Altered calcium handling and contractility in PTIP- mice. Previous work has suggested that altering $\mathrm{I}_{\text {to }}$ and prolonging APD can alter $\left[\mathrm{Ca}^{2+}\right]_{\mathrm{i}}$ levels and cardiac contractility (17). Accordingly, we assessed $\left[\mathrm{Ca}^{2+}\right]_{i}, \mathrm{I}_{\mathrm{Ca}, \mathrm{L}}$, and cellular contractility in apical LV myocytes from PTIP $^{+}$and PTIP- mice. First, cells were loaded with fluo-4AM, and calcium transients were recorded at different stimulation frequencies. As shown in Figure 7A, the amplitude of $\left[\mathrm{Ca}^{2+}\right]_{i}$ transients was significantly larger in PTIP- myocytes than in $\mathrm{PTIP}^{+}$myocytes at all pacing frequencies. We also mea- 
A

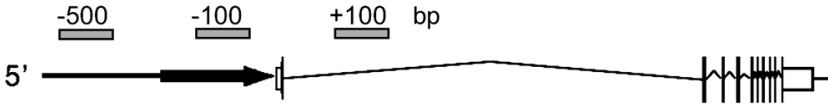
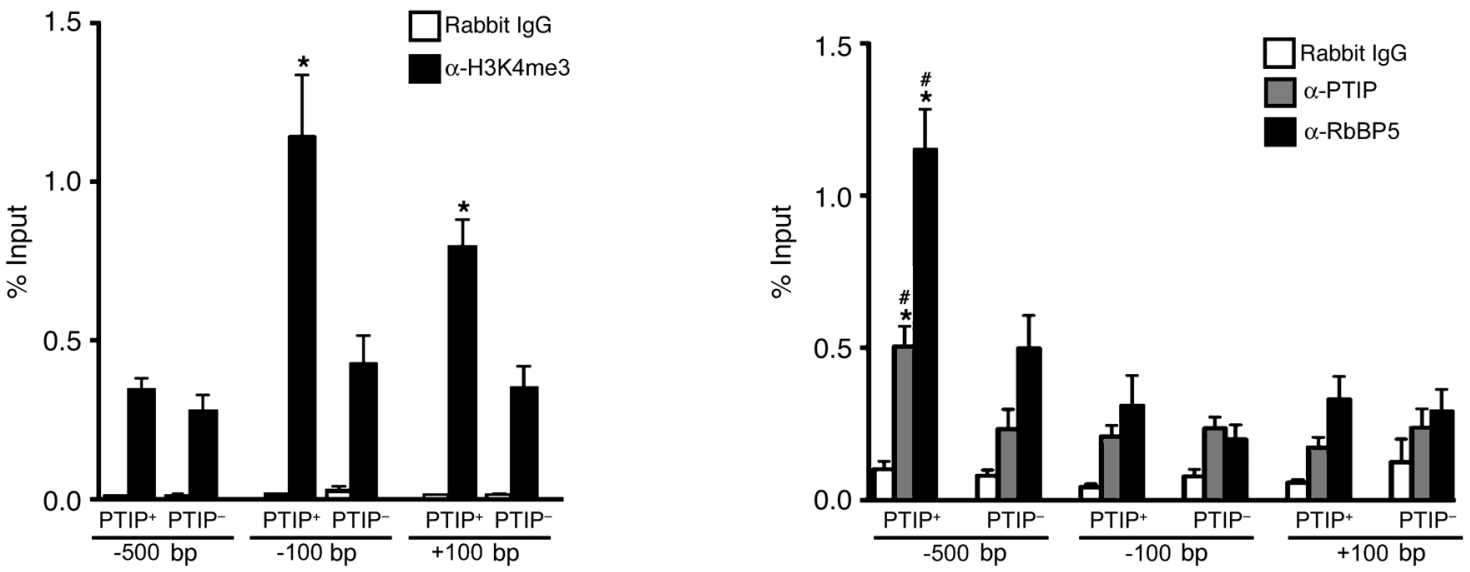

B
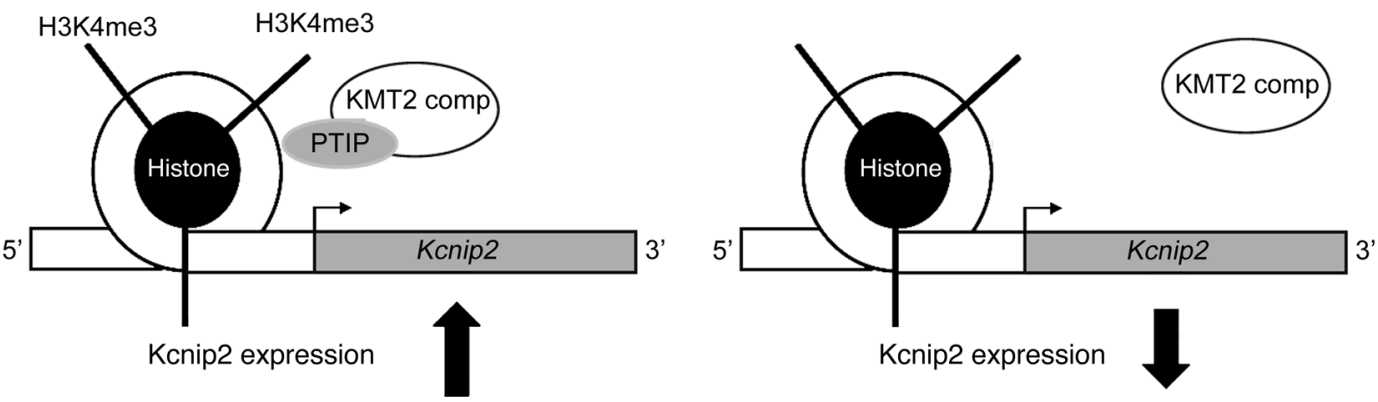

Figure 3

ChIP analysis of H3K4me3, PTIP, and RbBP5. (A) ChIP analysis was performed to study H3K4me3 enrichment at the Kcnip2 5 ' regulatory region. A schematic of the Kcnip2 transcript is shown. Boxes represent exons, and lines connecting boxes represent introns. Black boxes represent coding sequence, whereas white boxes represent untranslated region. Primers were designed that amplify DNA at -500 bp (primer 1 ), $-100 \mathrm{bp}$ (primer 2), and $+100 \mathrm{bp}$ (primer 3 ) relative to the first recognized ATG site (arrow tip). IP was performed with $20 \mu \mathrm{g}$ chromatin using $2 \mu \mathrm{g}$ anti-rabbit IgG and $2 \mu \mathrm{g}$ anti-H3K4me3 antibody in $\mathrm{PTIP}^{+}(n=4)$ and $\mathrm{PTIP}^{-}(n=4)$ mice. Enrichment for H3K4me3 marks is shown at primer set 1 (left), primer set 2 (middle), and primer set 3 (right). ${ }^{*} P<0.05$ versus PTIP- at the same primer set. ChIP was performed to study whether PTIP and RbBP5 localized to the Kcnip2 5' regulatory region. Primers were designed that amplify DNA at $-500 \mathrm{bp},-100 \mathrm{bp}$, and $+100 \mathrm{bp}$ relative to the first recognized Kcnip2 ATG site. IP was performed with $20 \mu \mathrm{g}$ chromatin using $4 \mu \mathrm{g}$ anti-rabbit IgG (white bars), $4 \mu \mathrm{g}$ rabbit anti-PTIP antibody (gray bars), or $4 \mu \mathrm{g}$ rabbit anti-RbBP5 (black bars) in $\mathrm{PTIP}^{+}(n=5)$ and $\mathrm{PTIP}^{-}(n=4)$ mice. Data are represented as percentage input (mean \pm SD). ${ }^{*} P<0.05$ versus PTIP-; ${ }^{*} P<0.05$ versus $\mathrm{PTIP}^{+}$at -100 and +100 bp. (B) Schematic illustrating how the decrease in Kcnip2 transcript expression is a direct result of PTIP deletion and the inability of PTIP- mice to maintain a KMT2 complex (comp.) and H3K4me3 marks at the $5^{\prime}$ regulatory region of the Kcnip2 gene.

sured $\mathrm{I}_{\mathrm{C}, \mathrm{L}}$ to determine whether the increase in $\left[\mathrm{Ca}^{2+}\right]_{\mathrm{i}}$ was at least partly due to an increase in this inward current. Figure $7 \mathrm{~B}$ shows peak $\mathrm{I}_{\mathrm{Ca}, \mathrm{L}}$ as a function of test pulse. Data revealed a significantly higher $\mathrm{I}_{\mathrm{Ca}, \mathrm{L}}$ in $\mathrm{PTIP}^{-}$mice as compared with that in $\mathrm{PTIP}^{+}$mice. In addition, measurements of myocyte contractility at different stimulation frequencies revealed that PTIP- $^{-}$mice have a higher fractional shortening than $\mathrm{PTIP}^{+}$mice (Figure 7C). These results suggest that attenuating $\mathrm{I}_{\text {to }}$ and prolonging the APD alters $\left[\mathrm{Ca}^{2+}\right]_{\mathrm{i}}$ levels and excitation contraction coupling in cardiomyocytes.

In vivo assessment of cardiac function. We assessed cardiac structure and function noninvasively over time by echocardiography in isoflurane-anesthetized PTIP- and PTIP $^{+}$mice, with and without tamoxifen at 3 months, 6 months, and 9 months. Surprisingly, the echoes revealed significant and sustained improvements in
LV systolic functions in the PTIP- $^{-}$mice after tamoxifen injection, as measured by ejection fraction (Figure 8A) and velocity of circumferential fractional shortening (Figure 8B), a load-independent assessment of systolic function (18). Despite the increase in systolic function in the PTIP- hearts, no alterations in echo parameters of chamber size, wall thickness, or heart rate were observed (Supplemental Table 2).

Pathology. At the end of 9 months, heart tissue was harvested, and histology was performed. The PTIP- mice showed no evidence of gross cardiac hypertrophy, as measured by LV weight to tibia length (Figure 8C), or cellular hypertrophy, as measured by myocyte cross-sectional area (Figure 8E). Myocardial fibrosis was quantified by picrosirius red staining, with no significant differences observed in the 2 groups (Figure 8D). 
A

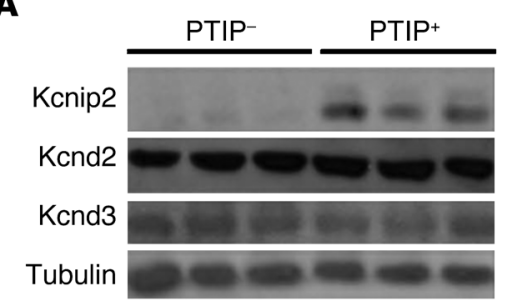

B

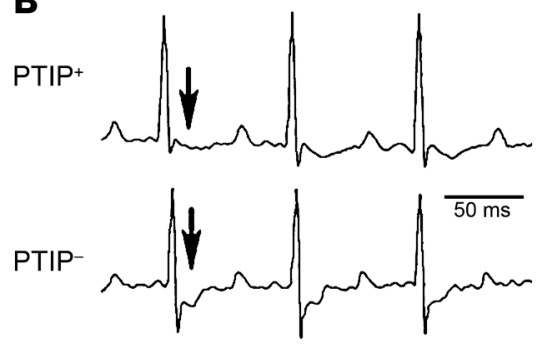

C

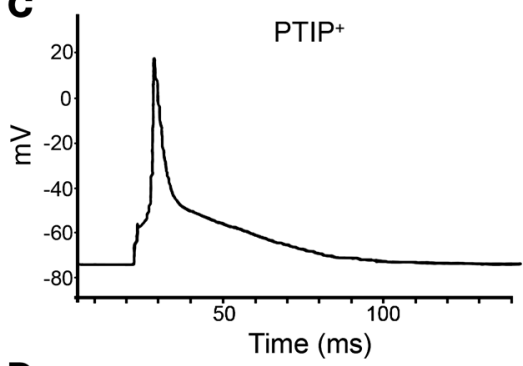

D

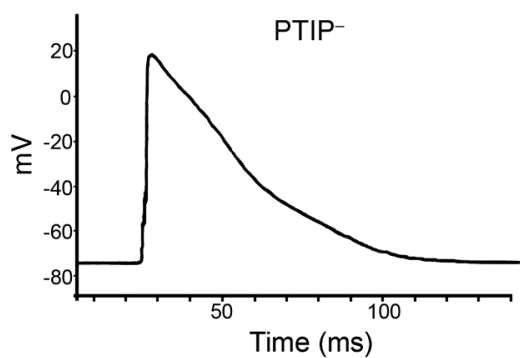

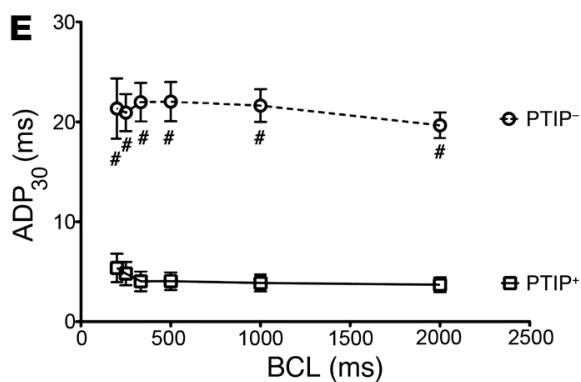

$\mathbf{F}$

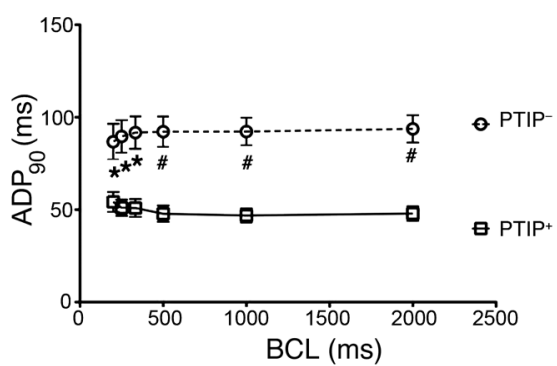

Figure 4

Effects of cardiac-specific PTIP deletion on Kcnip2, EKG, and APD. (A) Western blot performed on LV samples from PTIP- and PTIP+ mice 4 weeks after tamoxifen injection. Lanes were probed with antibodies to Kcnip2, Kcnd2, Kcnd3, and $\beta$-tubulin. (B) EKGs from a lead I configuration in PTIP+ and PTIP- mice 4 weeks after tamoxifen injection. Arrows point to the ST segment in the PTIP+ mice and depressed ST segment in the PTIP- mice. (C and D) Representative action potential tracings from ventricular myocytes in (C) $\mathrm{PTIP}^{+}$and (D) PTIP- mice. APD was measured at $(E) 30 \%$ and $(\mathbf{F}) 90 \%$ repolarization in PTIP + mice (number of animals $[N]=4$, number of cells $[n]=15)$ and PTIP- mice $(N=4, n=10)$. BCL, basic cycle length. ${ }^{\star} P<0.05,{ }^{\#} P<0.001$. Data shown for $\mathbf{E}$ and $\mathbf{F}$ are mean \pm SEM.

Susceptibility to ventricular premature beats. To determine whether PTIP deletion and the associated changes in $\mathrm{I}_{\mathrm{Na}}$ and $\left[\mathrm{Ca}^{2+}\right]_{i}$ predispose to a susceptibility to ventricular arrhythmias, lightly anesthetized 12-week-old PTIP ${ }^{+}$and PTIP $^{-}$mice were injected with isoproterenol and caffeine. PVCs were counted for the first 5 minutes after the initial PVCs, and data were analyzed as PVCs per minute. As shown in Figure 9A, PTIP- mice $(n=3)$ demonstrated a significantly higher number of PVCs per minute than $\mathrm{PTIP}^{+}$mice $(n=4)$. One PTIP ${ }^{+}$mouse showed no evidence of PVCs, and the other $\mathrm{PTIP}^{+}$mice demonstrated intermittent isolated PVCs. In contrast, all PTIP- mice developed a sustained pattern of ventricular bigeminy, in which every other beat was a PVC (Figure 9B).

\section{Discussion}

We tested the necessity for the PTIP-dependent H3K4me pathway in a fully differentiated, nondividing cell type, the cardiomyocyte. $\mathrm{H} 3 \mathrm{~K} 4 \mathrm{me}$ marks are imprinted through the actions of the $\operatorname{TrG}$ family of genes during development and correlate with actively expressed genes. Genetic experiments in flies suggest that such epigenetic marks are inherited from mother to daughter cells (19), but the role of $\mathrm{H} 3 \mathrm{~K} 4 \mathrm{me}$ in terminally differentiated cells had not been directly addressed. Our data demonstrate that PTIP deletion in a largely nondividing cell population results in a significant reduction of global, steady-state $\mathrm{H} 3 \mathrm{~K} 4 \mathrm{me} 3$ levels and alterations in the transcriptome. This suggests a role for KMT2 complexes not just in establishing active chromatin domains but also in the maintenance of the differentiated state over time. Furthermore, the loss of PTIP-mediated H3K4me results in significant changes in the physiology of the cardiomyocytes, suggesting that epigenetic changes can be the direct cause of abnormal cellular or disease phenotypes, even in nondividing, aging cell types.
PTIP is part of a conserved KMT2C/D histone methyltransferase complex and, at least in one case, is thought to link these complexes to tissue-specific DNA-binding proteins (11). Germline deletion of Paxip1, which encodes PTIP, results in global reduction but not complete ablation of $\mathrm{H} 3 \mathrm{~K} 4 \mathrm{me}$ levels and in early embryonic lethality in both flies and mice (11). Furthermore, deletion of Paxip1 in either neural stem cells or embryonic stem cells also reduces $\mathrm{H} 3 \mathrm{~K} 4 \mathrm{me}$ and inhibits differentiation (11). Thus, the loss of PTIP in developing systems is consistent with the hypothesis that $\mathrm{H} 3 \mathrm{~K} 4 \mathrm{me}$ is a positive epigenetic mark necessary for lineage-specific differentiation. Furthermore, Paxip1 germline null mutants are more severe and arrest earlier in development than any of the individual KMT2 mutants generated to date $(20,21)$. This, together with protein purification data $(11,13,14)$, suggests that PTIP interacts with more than one H3K4 methyltransferase. Thus, we used the Paxip1 conditional allele as a means to reduce global levels of $\mathrm{H} 3 \mathrm{~K} 4$ methylation in the adult heart. As a result, marked changes in the cardiomyocyte transcriptional program were observed and alterations in the electrophysiological properties followed as a result.

Epigenetic regulatory pathways have been linked to a variety of diseases. Translocations of the KMT2A gene, which generate fusion proteins that have lost the SET domain, are gain-of-function mutations that promote leukemias (22). Overexpression of the H3K27 methylase EZH2 is linked to prostate cancer progression (23). However, loss-of-function mutations in genes encoding components of the $\mathrm{H} 3 \mathrm{~K} 4 \mathrm{me}$ complexes have not been described in humans. In mice, multiple germline mutant alleles of KMT2A are embryonic lethal $(20,21,24)$, thus making it difficult to assess the specific roles of KMT2A in adult cell populations. However, a neural stem cell-specific deletion of KMT2A results in increased gliogenesis at the expense of the neuronal lineage (4). A germline SET domain 


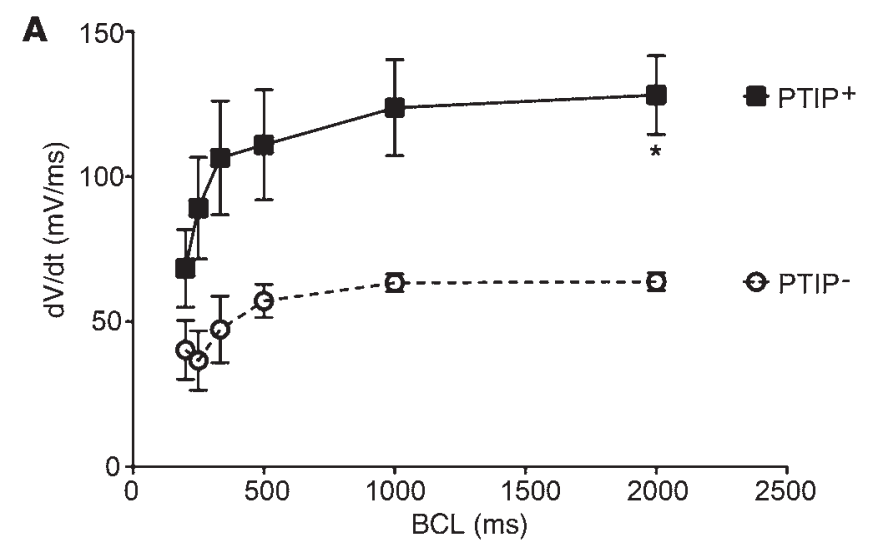

B

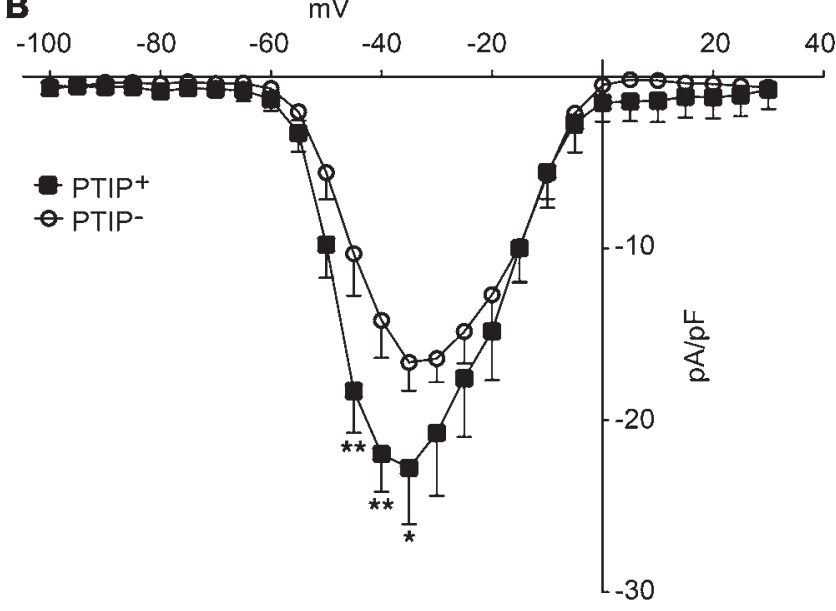

Figure 5

PTIP deletion reduces $\mathrm{dV} / \mathrm{dt}$ and $\mathrm{I}_{\mathrm{Na}}$. (A) $\mathrm{dV} / \mathrm{dt}$ measured in PTIP+ myocytes $(n=3, n=6)$ and PTIP- myocytes $(n=2, n=4)$. (B) $I_{\mathrm{Na}}$ measured in PTIP+ myocytes $(N=2, n=4)$ and PTIP- myocytes $(N=2, n=4)$. ${ }^{\star} P<0.05,{ }^{*} P<0.01$. Data are mean \pm SEM.

deletion of KMT2C is less severe and affects adipogenesis more specifically (25). Interestingly, PTIP also binds to KMT2C (13) and has been linked to adipocyte differentiation directly (26).

From a cardiac disease standpoint, very little is known about the importance of histone methylation marks in regulating disease states. Previous work by Kaneda et al. described the changes in histone methylation that accompany cardiac disease states (5). In particular, they noted that, in rat and human heart failure samples, the 2 types of histone methylation marks that are altered, presumably as a result of the disease state, are activating H3K4me3 marks and repressive $\mathrm{H} 3 \mathrm{~K} 9 \mathrm{me} 3$ marks. Currently, it is unclear whether the changes in these marks are merely associated with disease states or whether they contribute to the initiation and progression of the disease states. The data presented here strongly argue that epigenetic changes can be sufficient to cause disease by altering the transcriptional profile of fully differentiated cardiomyocytes. Such alterations can induce abnormal electrophysiological properties, which, in our studies, impact calcium handling and actually improve contractility, but ultimately sensitize the heart to arrhythmias.

Among the most significant gene affected by the reduction in H3K4me3 marks is Kcnip2, which controls multiple facets of the electrical cardiac phenotype. Although Kcnip2 is downregulated in human heart failure $(5,8)$ and confers susceptibility to ventricular tachycardia in murine models $(5,8,9)$, little is known about its regulation. Previous work has demonstrated that Kcnip2 is necessary for the functional regulation of both $\mathrm{I}_{\mathrm{to}}$ and $\mathrm{I}_{\mathrm{Na}}(27)$. It was shown that posttranscriptional gene silencing of Kcnip2 suppressed both $\mathrm{I}_{\text {to }}$ and $\mathrm{I}_{\mathrm{Na}}$ and reduced $\mathrm{Na}$ channel $\alpha(\operatorname{Scn} 5 a)$ and $\beta 1(\operatorname{Scn} 1 b)$ subunit mRNA levels in neonatal rat ventricular myocytes. On the other hand, silencing of $\mathrm{Na}_{v} \beta 1$ also reduced Kcnip2 mRNA and protein as well as $\mathrm{K}_{\mathrm{v}} 4$.x proteins, resulting in significantly decreased $\mathrm{I}_{\mathrm{Na}}$ and $I_{\text {to }}(27)$. Our data strongly support the above interactions. They demonstrate that, in addition to reducing $\mathrm{I}_{\text {to }}$ and prolonging APD, PTIP deletion-induced attenuation of Kcnip2 results in PR prolongation on EKG and reduced $\mathrm{I}_{\mathrm{Na}}$ and slowed action potential upstroke velocity in the myocytes. These results are consistent with the notion that Kcnip2 interacts closely with $\mathrm{K}_{\mathrm{V}} 4 . \mathrm{x}, \mathrm{Nav} \beta 1$ and $\mathrm{Na}_{V} 1.5$ and that suppressing Kcnip2 attenuates $\mathrm{I}_{\mathrm{Na}}$. Thus, the maintenance of $\mathrm{H} 3 \mathrm{~K} 4 \mathrm{me}$ marks by the PTIP complex is critical to the regulation of Kcnip2 and the electrophysiological phenotype.

$I_{\text {to }}$ plays a significant role in regulating phase I of the cardiac action potential in rodents and in humans. In contrast to large mammals, mice and rats have small triangular action potentials that are regulated by $\mathrm{I}_{\mathrm{to}}$ to a large extent (17). Previous work has suggested that an increased APD invokes increased $\left[\mathrm{Ca}^{2+}\right]_{\mathrm{i}}$, due, at least partly, to increased $\mathrm{I}_{\mathrm{Ca}, \mathrm{L}}(17)$. Our data support the notion that the $\mathrm{I}_{\mathrm{to}}$ attenuation-induced increased APD results in an increase in $\mathrm{I}_{\mathrm{Ca}, \mathrm{L}}$ and $\left[\mathrm{Ca}^{2+}\right]_{i}$. These changes in $\left[\mathrm{Ca}^{2+}\right]_{i}$ ultimately increase cellular cardiac contractility in vitro and systolic function in vivo. Our results are consistent with previous work that revealed that decreasing $\mathrm{I}_{\mathrm{to}}$ by inhibitors, such as 4-AP, or by genetic manipulation prolongs the action potential, increases calcium influx, elevates $\left[\mathrm{Ca}^{2+}\right]_{i}$, and increases contractility $(28,29)$. Taken together with previous reports, our data reiterate the importance of the transient outward current in regulating excitation-contraction coupling in cardiac cells.

Mice expressing dominant-negative Kcnd 2 have decreased $\mathrm{I}_{\text {to }}$ and improved contractility; however, those mice exhibit the early onset of cardiac hypertrophy, chamber dilatation, and interstitial fibrosis (29). One might predict that the PTIP- mice would also develop hypertrophy because of increased $\left[\mathrm{Ca}^{2+}\right]_{i}$. However, despite a significant and sustained improvement in systolic cardiac function, PTIP- mice do not demonstrate a hypertrophic phenotype as measured by myocyte cross-sectional area or gravimetric analysis. Our qPCR gene expression analysis demonstrated that PTIP deletion was associated with an elevated Nppa level, both at 1 and 9 months after PTIP deletion. Although Nppa elevations are consistent with hypertrophy, PTIPmice have decreased mRNA expression of $\alpha 1$ skeletal muscle actin (Acta1), a protein that is upregulated in the development of hypertrophy, as compared with that of $\mathrm{PTIP}^{+}$mice at 9 months of age. Furthermore, PTIP $^{-}$and PTIP $^{+}$mice have similar amounts of $\beta \mathrm{MHC}$ $(M y b 7)$ and Nppb, fetal genes that are upregulated in hypertrophy and failure. Thus, although PTIP- mice have increased $\left[\mathrm{Ca}^{2+}\right]$, the hypertrophic phenotype may be blunted in the absence of PTIP, because of the inability to upregulate genes necessary for the development of hypertrophy. Therefore, these results suggest the possibility that at least some hypertrophy-associated genes may require new $\mathrm{H} 3 \mathrm{~K} 4 \mathrm{me} 3$ marks in response to stress or injury and that such maladaptive responses may be controlled by epigenetic mechanisms.

Cardiac repolarization occurs in a heterogeneous manner such that subepicardial cells have higher repolarization gradients than subendocardial cells (7). Disruption of this gradient is a hallmark of diseased myocardium and predisposes to ventricular arrhythmias $(7,9)$. 
A
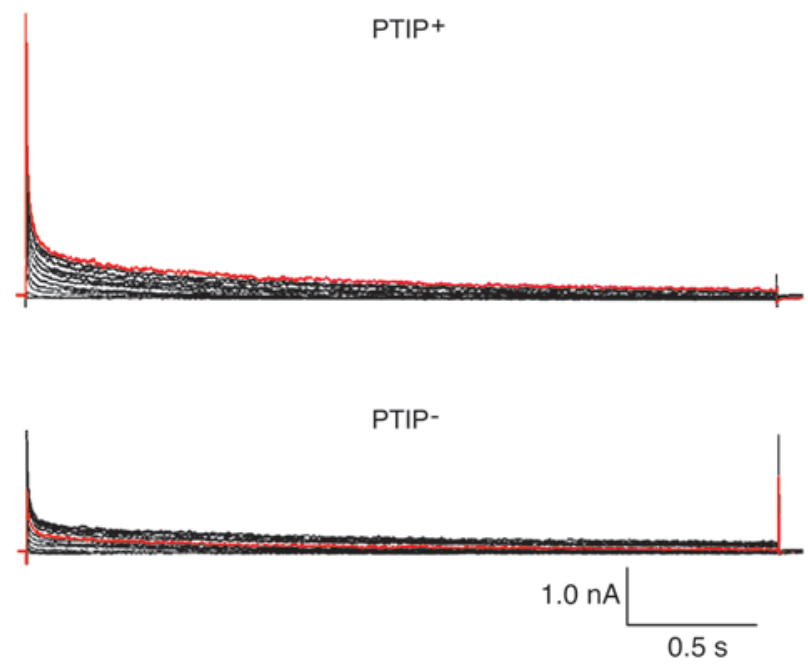

B

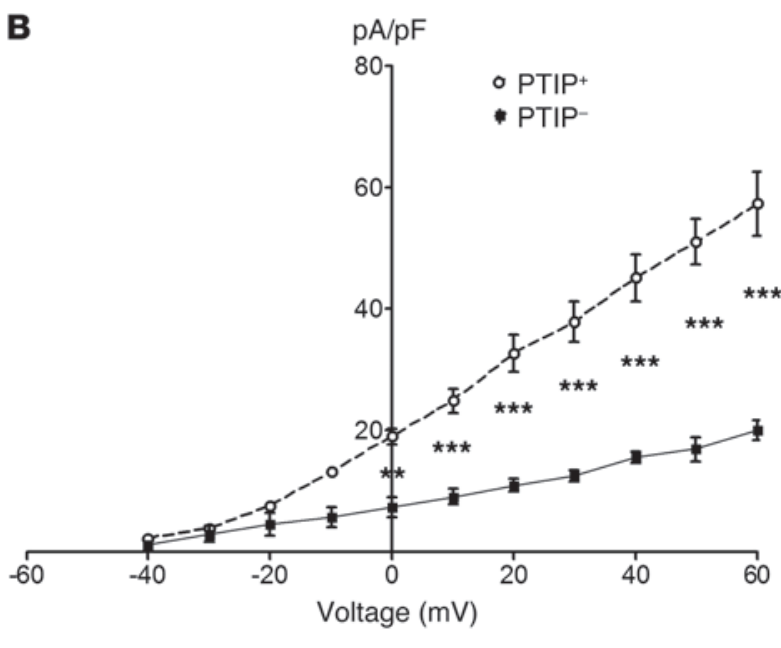

Figure 6

PTIP deletion reduces $I_{\text {to. }}$ (A) Superimposed whole cell outward $\mathrm{K}^{+}$current traces recorded from PTIP+ and PTIP- mice. (B) $I_{\text {to }}$ current-voltage relationships for PTIP+ myocytes $(N=2, n=6)$ and PTIP- myocytes $(N=2, n=4){ }^{* \star} P<0.01,{ }^{* \star *} P<0.001$. Data are mean $\pm \mathrm{SEM}$.

Prior work has shown that genetic deletion of Kcnip2 alters the repolarization gradient and that Kcnip2 is heterogeneously expressed across the ventricular wall in humans and in mice $(30,31)$. How the repolarization gradient is formed and maintained is incompletely understood. Our data suggest that $\mathrm{H} 3 \mathrm{~K} 4 \mathrm{me} 3$ epigenetic marks may be partly responsible for maintaining the cardiac repolarization gradient. In order to insure that the heterogeneous expression of Kcnip2 does not bias our results, we performed ChIP assays from ventricular tissue in both PTIP ${ }^{+}$and PTIP- mice and used apical myocytes in both groups for our patch clamp experiments.

If changes in histone methylation can alter the transcriptome of a terminally differentiated cell, how might such changes arise in the absence of mutations in PTIP or other components of the H3K4 methyltransferase machinery? Epigenetic changes are likely to correlate with altered gene expression due to stressful physiological conditions. However, these changes may not be reset once the stress is alleviated, because the epigenetic changes confer indelible changes in the transcriptome. For example, complications can continue to develop in diabetic patients even after glycemic control is achieved (32). In cell and animals models of hyperglycemia, gene expression patterns may be permanently altered even after normal glucose levels are reinstituted. Such permanent alterations are thought to be due to epigenetic changes at gene-specific promoter regions. Histone deacetylase inhibitors are now used as anticancer or anticonvulsive drugs but can lead to unintended alterations in the methylation of histones in a variety of tissues (33-35). Further-

Figure 7

PTIP deletion increases $\mathrm{Ca}^{2+}$ transients, $\mathrm{I}_{\mathrm{Ca}, \mathrm{L}}$, and contractility. (A) $\mathrm{Ca}^{2+}$ transients expressed as change in fluorescence $(\mathrm{F})$ over control fluorescence (Fo) in PTIP+ myocytes $(N=2, n=7$ cells) and PTIP- myocytes ( $N=2, n=6$ cells). Cells were loaded with fluo$4 \mathrm{AM}$ and field stimulated at 1 to $6 \mathrm{~Hz}$. (B) $\mathrm{I}_{\mathrm{Ca}, \mathrm{L}}$ current-voltage relationships for $\mathrm{PTIP}^{+}$myocytes $(N=2, n=7)$ and $\mathrm{PTIP}^{-}$myocytes $(N=2, n=6)$. (C) PTIP- myocytes show significantly higher fractional shortening that $\mathrm{PTIP}^{+}$myocytes at $1-$ to $6-\mathrm{Hz}$ pacing. ${ }^{\star} P<0.05,{ }^{* * *} P<0.001$. All data are mean \pm SEM. more, the metabolic memory hypothesis presupposes that once a pattern of histone methylation is reset by stress, that pattern is maintained or replicated. We have yet to determine whether cardiomyocytes are also susceptible to stress-induced changes in epigenetic memory, as, for example, in chronic hypertension followed by pharmacological interventions. In this study, we elected to use an inducible model to demonstrate that postdevelopmental changes

\section{A}

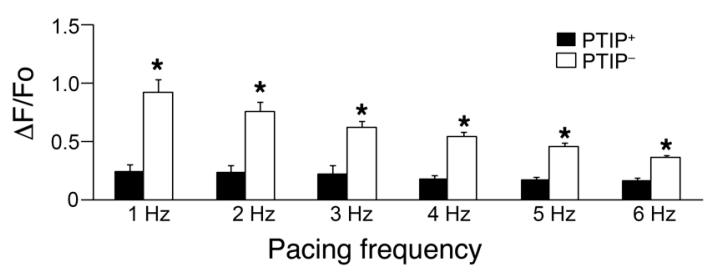

B

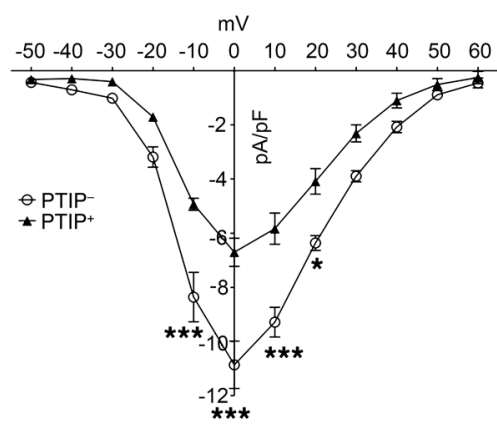

C

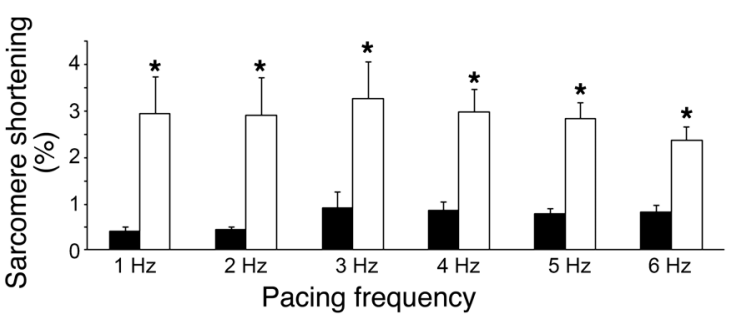


A

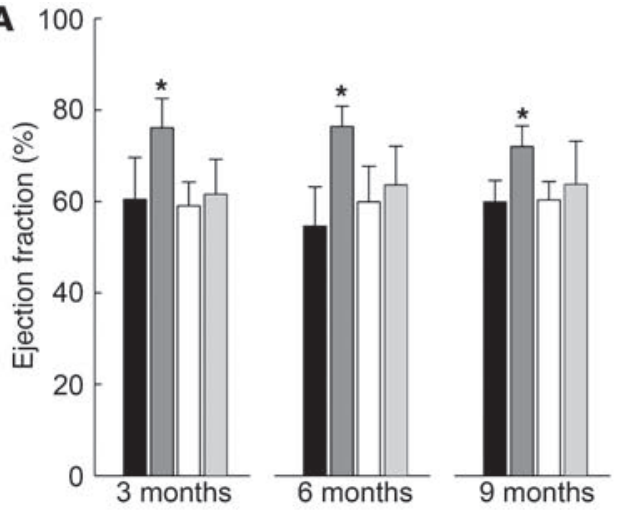

B

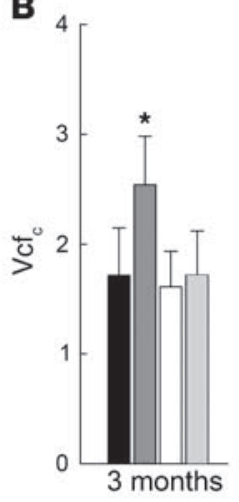

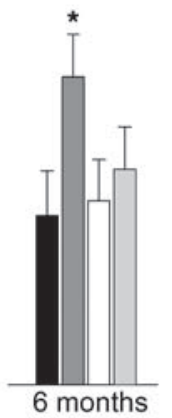
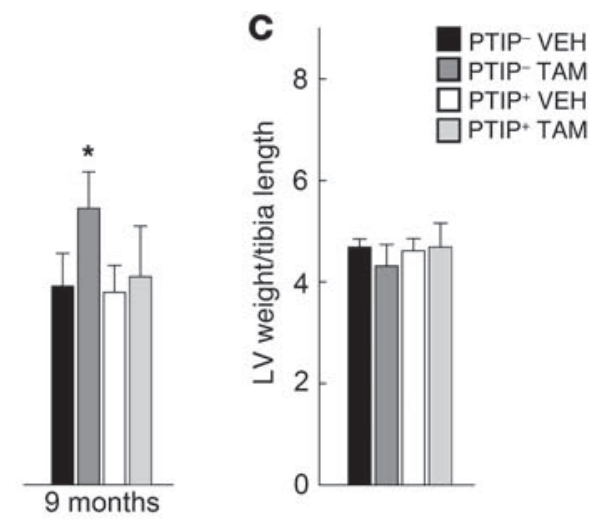

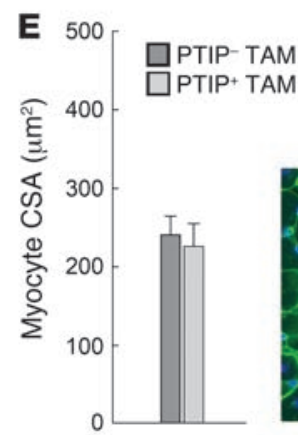

PTIP- TAM

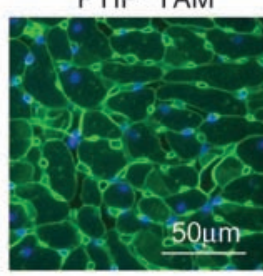

$\mathrm{PTIP}^{+} \mathrm{TAM}$

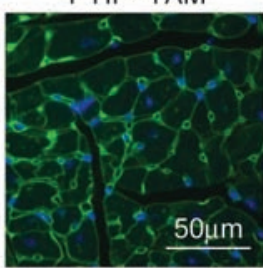

\section{Figure 8}

PTIP- mice show increased in vivo LV function. Eight-week-old PTIP+ were injected with tamoxifen (TAM; $n=10)$ or vehicle $($ VEH; $n=5)$, and PTIP- mice were injected with tamoxifen $(n=12)$ or vehicle $(n=6)$. Echo was subsequently performed at 3 months, 6 months, and 9 months of age. (A) LV systolic function assessed by ejection fraction. (B) Velocity of circumferential fractional shortening $\left(\mathrm{Vcf}_{\mathrm{c}}\right)$. ${ }^{\star} P<0.05$ versus $\mathrm{PTIP}^{-}$vehicle, $\mathrm{PTIP}^{+}$vehicle, and PTIP+ tamoxifen. (C) LV weight normalized to tibial length at 9 months. (D) The percentage fibrosis in paraffin-embedded sections of hearts from tamoxifen-injected 9-month-old PTIP+ mice $(n=6)$ and PTIP- mice $(n=6)$ stained with picrosirius red and NB green. LV myocardial fibrosis was measured in each of 20 sections per heart. (E) Sections were also stained with wheat germ agglutinin and DAPI. Myocyte cross-sectional area in the LV free wall was measured in approximately 100 myocytes per heart. Scale bar: $100 \mu \mathrm{m}$ (D); $50 \mu \mathrm{m}$ (E). All data are mean \pm SD.

in epigenetic machinery, such as that which may occur as a result of a pathophysiological insult, are mechanistically relevant. Our model suggests that such epigenetic changes must be considered, as they can be a cause and not just an effect of disease.

In conclusion, we believe this study is the first to demonstrate that maintenance of $\mathrm{H} 3 \mathrm{~K} 4 \mathrm{me}$ marks is necessary for maintaining the expression of some genes that are critical to regulating homeostasis in fully differentiated tissue. Furthermore, our phenotypic analysis demonstrates that Kcnip2, a gene at least partly regulated by $\mathrm{H} 3 \mathrm{~K} 4 \mathrm{me}$ marks, is important in regulating many facets of the electrophysiological phenotype, including APD, $\mathrm{I}_{\mathrm{Na}}, \mathrm{I}_{\mathrm{to}},\left[\mathrm{Ca}^{2+}\right]_{\mathrm{i}}$, cardiac contractility, and susceptibility to ventricular premature beats. Since it is known that Kcnip2 is downregulated in human models of heart failure and attenuation of the transient outward current is a hallmark of diseased myocardium, our results provide the first evidence to our knowledge that genes that are important in pathophysiology (e.g., arrhythmogenesis and alterations in excitation contraction coupling) may, indeed, be regulated by the same epigenetic H3K4me marks that are important in establishing body patterns in Drosophila.

\section{Methods}

Animals. Mice were kept according to NIH guidelines. All animal studies were reviewed and approved by the University Committee on Use and Care of Animals at the University of Michigan.
Tamoxifen. Unless otherwise specified, mice were injected i.p. with tamoxifen $(20 \mathrm{mg} / \mathrm{kg})$ dissolved in peanut oil (vehicle) at 8 weeks of age over a 5-day period.

qPCR and array. LV samples were harvested, and RNA was isolated and sent to the University of Michigan Comprehensive Cancer Center Affymetrix and Microarray Core Facility or used for $\mathrm{qPCR}$ with TaqMan probes. Array data are available at the GEO database (accession no. GSE20570; http://www.ncbi.nlm.nih.gov/geo/query/acc.cgi).

Immunoblotting. LV tissue samples were used for immunoblotting and performed using PTIP antibodies as previously described. Other antibodies used include anti-H3 (Abcam, ab1791), anti-H3K4me3 (Abcam, ab8580), anti-RbBP5 (Bethyl, A300-109A), anti-Kcnip2 (NeuroMab, 75-004), antiKcnd2 (Millipore), and anti-Kcnd3 (NeuroMab, 75-017).

ChIP. Ventricles were harvested and minced into 1- to $2-\mathrm{mm}^{2}$ pieces. For PTIP and RbBP5 studies, minced tissue was crosslinked with $2 \mathrm{mM}$ disuccinimidyl glutarate for 45 minutes and then crosslinked with $1 \%$ formaldehyde in culture media for 15 minutes. For H3K4me3 marks, minced tissue was cross-linked with $1 \%$ formaldehyde in culture media for 15 minutes. The protocol was then followed as previously described (11). Primers used for qPCR are available in Supplemental Table 3. Antibodies for ChIP include rabbit IgG $(4 \mu \mathrm{g})$, rabbit anti-PTIP $(4 \mu \mathrm{g})$, rabbit anti-RbBP5 (Bethyl, A300-109A), and rabbit anti-H3K4me3 (Abcam, ab8580) (4 $\mu \mathrm{g})$.

Immunoprecipitation. Immunoprecipitation was performed on formaldehyde crosslinked chromatin, which consists of DNA and its associated 

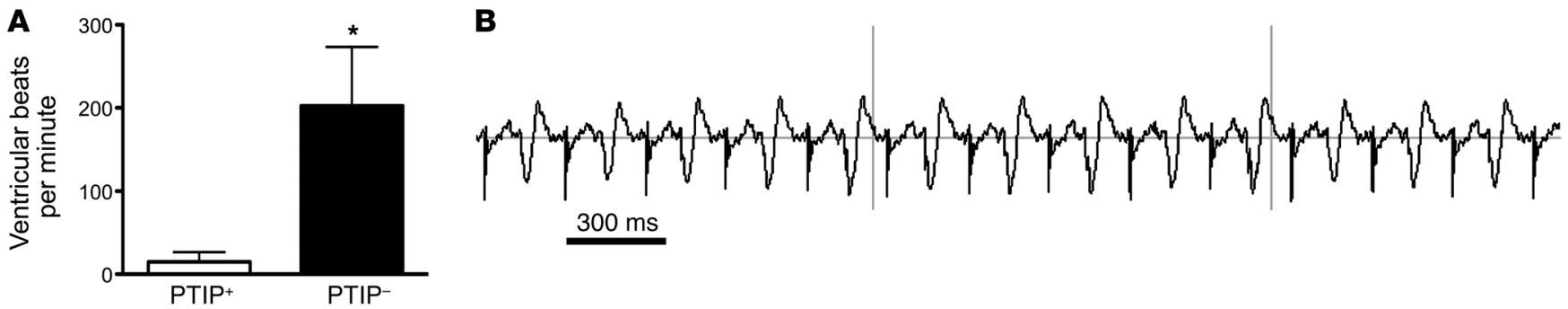

Figure 9

PTIP- mice show increased susceptibility to PVCs. Twelve-week-old PTIP+ mice $(n=4)$ and PTIP- mice $(n=3)$ were anesthetized with Avertin and injected i.p. with isoproterenol $(2 \mathrm{mg} / \mathrm{kg})$ and caffeine $(180 \mathrm{mg} / \mathrm{kg})$. (A) Continuous EKG recordings were performed. PVCs were counted, and analysis revealed that $\mathrm{PTIP}^{-}$mice had significantly more PVCs than $\mathrm{PTIP}+$ mice. Data are mean $\pm \mathrm{SD}$. ${ }^{\star} P<0.05$ vs. PTIP+. (B) Representative example of the pattern of ventricular bigeminy that was observed in all PTIP- mice.

proteins. We used $4 \mu \mathrm{g}$ rabbit anti-PTIP antibody and $4 \mu \mathrm{g}$ rabbit IgG antibody as a control.

Echocardiography. Echo was performed as previously described using isoflurane anesthesia (36).

Myocyte isolation. For myocyte isolations, mice were injected i.p. with heparin (150 units/mouse). After 20 minutes, the mice were euthanized by $\mathrm{CO}_{2}$, followed by cervical dislocation. The heart was removed from the chest, auxiliary tissue was removed, and the aorta was cannulated. The heart was then perfused with myocyte and digestion buffer. An apical piece of LV tissue was then removed, mechanically disaggregated, and separated by centrifugation.

Fluo-4AM and calcium transients and sarcomere shortening assays. Myocytes were isolated from PTIP ${ }^{+}$and PTIP- mice, and shortening assays and Fluo$4 \mathrm{AM}$ calcium transients were performed as previously described (37).

EKG. EKG was performed in conscious mice. Recordings were taken from a lead I and a lead II configuration.

Whole cell current clamp experiments. Action potentials were recorded at $37^{\circ} \mathrm{C}$ in current-clamp mode, using the Multiclamp 700B amplifier (Molecular Devices). Cells were paced, from 0.5 to $5 \mathrm{~Hz}$, with brief depolarizing pulses at 1.5- to 2-times threshold value, generated using a programmable digital stimulator (World Precision Instruments, DS8000). Action potential parameters (RMP; dV/dt; and APD 30, 50, 70, 90) were estimated using the pClamp 10 suite of programs. The bath solution contained $148 \mathrm{mmol} / \mathrm{l} \mathrm{NaCl}$, $0.4 \mathrm{mmol} / 1 \mathrm{NaH}_{2} \mathrm{PO}_{4}, 1 \mathrm{mmol} / 1 \mathrm{MgCl}_{2}, 5.5 \mathrm{mmol} / 1$ glucose, $5.4 \mathrm{mmol} / \mathrm{l} \mathrm{KCl}$, $1 \mathrm{mmol} / \mathrm{l} \mathrm{CaCl}_{2}$, and $15 \mathrm{mmol} / \mathrm{l} \mathrm{HEPES}$. The internal solution contained 148 $\mathrm{mmol} / 1 \mathrm{KCl}, 1 \mathrm{mmol} / \mathrm{l} \mathrm{MgCl}_{2}, 5 \mathrm{mmol} / \mathrm{l} \mathrm{EGTA}, 5 \mathrm{mmol} / \mathrm{l}$ HEPES, $2 \mathrm{mmol} / \mathrm{l}$ creatine, $5 \mathrm{mmol} / \mathrm{l} \mathrm{ATP}$, and $5 \mathrm{mmol} / \mathrm{l}$ phosphocreatine $(\mathrm{pH} 7.2, \mathrm{KOH})$.

Voltage clamp experiments. $\mathrm{I}_{\mathrm{to}}, \mathrm{I}_{\mathrm{Ca}, \mathrm{L}}$, and $\mathrm{I}_{\mathrm{Na}}$ properties were studied using the standard patch-clamp technique $(38,39)$. Experiments were carried out using a Multiclamp 700B amplifier (Molecular Devices). Data were acquired and analyzed using the PCLAMP 10 suite of programs (Axon Instruments). Borosilicate glass electrodes were pulled with a Brown-Flaming puller (model P-97, Sutter Instrument Company), yielding 2-4 mOhm tip resistances when filled with pipette solution to enable proper voltage control.

$\mathrm{I}_{\text {to }}$ recordings were conducted at room temperature $\left(21^{\circ} \mathrm{C}-22^{\circ} \mathrm{C}\right)$ with the following pipette filling solution: $135 \mathrm{mmol} / 1 \mathrm{KCL}, 1 \mathrm{mmol} / 1 \mathrm{MgCl}_{2}$, $5 \mathrm{mmol} / \mathrm{l} \mathrm{EGTA,} 5 \mathrm{mmol} / \mathrm{l} \mathrm{HEPES}$, and $5 \mathrm{mmol} / \mathrm{l}$ glucose ( $\mathrm{pH} 7.2$, with $\mathrm{KOH}$ ). External solutions contained $136 \mathrm{mmol} / \mathrm{l} \mathrm{NaCl}, 2 \mathrm{mmol} / 1 \mathrm{MgCl}_{2}, 4 \mathrm{mmol} / \mathrm{l}$ $\mathrm{KCL}, 1 \mathrm{mmol} / \mathrm{l} \mathrm{CaCl}_{2}, 10 \mathrm{mmol} / \mathrm{l} \mathrm{HEPES}$, and $15 \mathrm{mmol} / 1$ glucose ( $\mathrm{pH} 7.4$, with $\mathrm{NaOH})$. TTX $(30 \mu \mathrm{M})$ was added to block $\mathrm{I}_{\mathrm{Na}}$. $\mathrm{I}_{\text {to }}$ was recorded using a step protocol with a holding potential of $-70 \mathrm{mV}$ and stepping from $-40 \mathrm{mV}$ to $+60 \mathrm{mV}$ in $10 \mathrm{mV}$ increments of 5-second duration at each potential.

$\mathrm{I}_{\mathrm{Ca}, \mathrm{L}}$ measurements were performed at $37^{\circ} \mathrm{C}$ with the following pipette filling solution: $20 \mathrm{mmol} / \mathrm{l} \mathrm{CsCl}, 110 \mathrm{mmol} / \mathrm{l} \mathrm{Cs}$-aspartate, $1 \mathrm{mmol} / \mathrm{l}$ $\mathrm{MgCl}_{2}, 5 \mathrm{mmol} / \mathrm{l} \mathrm{MgATP}, 0.1 \mathrm{mmol} / \mathrm{l} \mathrm{GTP}, 5 \mathrm{mmol} / 1 \mathrm{Na}_{2}$ Phosphocreatine,
$10 \mathrm{mmol} / 1 \mathrm{EGTA}$, and $10 \mathrm{mmol} / 1$ HEPES (pH 7.2, with CsOH). External solution contained $136 \mathrm{mmol} / \mathrm{l}$ TEA-Cl, $5.4 \mathrm{mmol} / \mathrm{l} \mathrm{CsCl}, 0.8 \mathrm{mmol} / \mathrm{l}$ $\mathrm{MgCl}_{2}, 4 \mathrm{mmol} / 1 \mathrm{KCL}, 2 \mathrm{mmol} / 1 \mathrm{CaCl}_{2}, 10 \mathrm{mmol} / 1 \mathrm{HEPES}$, and $10 \mathrm{mmol} / \mathrm{l}$ glucose ( $\mathrm{pH} 7.4$, with $\mathrm{CsOH}$ ). $\mathrm{I}_{\mathrm{Ca}, \mathrm{L}}$ was assessed using the following protocol: from a holding potential of $-90 \mathrm{mV}$, cells were stepped to $-50 \mathrm{mV}$ for $150 \mathrm{~ms}$ and then to various test potentials $(-40$ to $60 \mathrm{mV}, 10 \mathrm{mV}$ increments, $300 \mathrm{~ms}$ duration, $400 \mathrm{~ms}$ interpulse intervals).

$\mathrm{I}_{\mathrm{Na}}$ was measured at room temperature $\left(21^{\circ} \mathrm{C}-22^{\circ} \mathrm{C}\right)$ with the following pipette filling solution: $5 \mathrm{mmol} / \mathrm{l} \mathrm{NaCl}, 135 \mathrm{mmol} / \mathrm{l} \mathrm{CsF}, 10 \mathrm{mmol} / \mathrm{l}$ EGTA, $5 \mathrm{mmol} / \mathrm{l} \mathrm{MgATP}$, and $5 \mathrm{mmol} / \mathrm{l}$ HEPES (pH 7.2). The extracellular solution contained $5 \mathrm{mmol} / \mathrm{l} \mathrm{NaCl}, 1 \mathrm{mmol} / 1 \mathrm{MgCl}_{2}, 1 \mathrm{mmol} / \mathrm{C} \mathrm{CaCl}_{2}$, $0.1 \mathrm{mmol} / 1 \mathrm{CdCl}_{2}, 11 \mathrm{mmol} / 1$ glucose, $132.5 \mathrm{mmol} / 1 \mathrm{CsCl}$, and $20 \mathrm{mmol} / 1$ HEPES ( $\mathrm{pH}$ 7.35). To assess the $\mathrm{I}_{\mathrm{Na}}$ density, cells were held at $-120 \mathrm{mV}$ and stepped to various test potentials ( -80 to $30 \mathrm{mV}, 5 \mathrm{mV}$ increments, $200 \mathrm{~ms}$ duration, 2,800 ms interpulse intervals).

Isoproterenol and caffeine studies. Mice were lightly anesthetized with Avertin $(0.025 \mathrm{mg} / \mathrm{kg})$ i.p., and body temperature was maintained at $37^{\circ} \mathrm{C}$. Mice were hooked up to a continuous EKG recording and injected i.p. with isoproterenol $(2 \mathrm{mg} / \mathrm{kg})$ and caffeine $(180 \mathrm{mg} / \mathrm{kg})$. Analysis was performed post hoc. PVCs were counted for 5 minutes after the onset of the first PVC.

Statistics. Statistical significance was calculated using 2-tailed Student's $t$ test to compare 2 groups and analysis of variance with Bonferroni correction to compare multiple groups. $P$ values of less than 0.05 were considered statistically significant. All data shown are mean \pm SEM unless otherwise specified.

\section{Acknowledgments}

This work was funded in part by NIH grants DK073722 (to G.R. Dressler), DK082409 (to S.R. Patel), HL093338 (to S.M. Day), P01-HL039707, and P01- HL087226; the Leducq Foundation (to J. Jalife); and the American Heart Association 057035N (to A.B. Stein) and $0735464 Z$ (to T.J. Herron). We would like to acknowledge Kimber Converso-Baran for performing and interpreting the echo data.

Received for publication August 5, 2010, and accepted in revised form April 13, 2011.

Address correspondence to: Adam B. Stein or Gregory R. Dressler, 109 Zina Pitcher Dr., 2668 BSRB, Ann Arbor, Michigan, 48103, USA. Phone: 734.764.6528; Fax: 734.615.3326; E-mail: adamstei@ umich.edu (A.B. Stein). Phone: 734.764.6528; Fax: 734.763.2162; E-mail: dressler@umich.edu (G.R. Dressler). 
1. Litt MD, Simpson M, Gaszner M, Allis CD, Felsenfeld G. Correlation between histone lysine methylation and developmental changes at the chicken betaglobin locus. Science. 2001;293(5539):2453-2455.

2. Santos-Rosa $\mathrm{H}$, et al. Active genes are tri-methylated at K4 of histone H3. Nature. 2002;419(6905):407-411.

3. Ruthenburg AJ, Allis CD, Wysocka J. Methylation of lysine 4 on histone $\mathrm{H} 3$ : intricacy of writing and reading a single epigenetic mark. Mol Cell. 2007;25(1):15-30.

4. Lim DA, et al. Chromatin remodelling factor Mll1 is essential for neurogenesis from postnatal neural stem cells. Nature. 2009;458(7237):529-533.

5. Kaneda R, et al. Genome-wide histone methylation profile for heart failure. Genes Cells. 2009;14(1):69-77.

6. Tomaselli GF, Zipes DP. What causes sudden death in heart failure? Circ Res. 2004;95(8):754-763.

7. Costantini DL, et al. The homeodomain transcription factor Irx 5 establishes the mouse cardiac ventricular repolarization gradient. Cell. 2005;123(2):347-358

8. Radicke $S$, et al. Functional modulation of the transient outward current Ito by KCNE beta-subunits and regional distribution in human non-failing and failing hearts. Cardiovasc Res. 2006;71(4):695-703.

9. Kuo HC, et al. A defect in the Kv channel-interacting protein 2 (KChIP2) gene leads to a complete loss of I(to) and confers susceptibility to ventricular tachycardia. Cell. 2001;107(6):801-813.

10. Cho EA, Prindle MJ, Dressler GR. BRCT domaincontaining protein PTIP is essential for progression through mitosis. Mol Cell Biol. 2003;23(5):1666-1673.

11. Patel SR, Kim D, Levitan I, Dressler GR. The BRCTdomain containing protein PTIP links PAX2 to a histone $\mathrm{H} 3$, lysine 4 methyltransferase complex. Dev Cell. 2007;13(4):580-592.

12. Fang M, Ren H, Liu J, Cadigan KM, Patel SR, Dressler GR. Drosophila ptip is essential for anterior/posterior patterning in development and interacts with the PcG and trxG pathways. Development. 2009;136(11):1929-1938.

13. Cho YW, et al. PTIP associates with MLL3- and MLL4containing histone $\mathrm{H} 3$ lysine 4 methyltransferase complex. JBiol Chem. 2007;282(28):20395-20406.

14. Issaeva I, et al. Knockdown of ALR (MLL2) reveals ALR target genes and leads to alterations in cell adhesion and growth. Mol Cell Biol. 2007; 27(5):1889-1903

15. Kim D, Patel SR, Xiao H, Dressler GR. The role of
PTIP in maintaining embryonic stem cell pluripotency. Stem Cells. 2009;27(7):1516-1523.

16. Sohal DS, et al. Temporally regulated and tis sue-specific gene manipulations in the adult and embryonic heart using a tamoxifen-inducible Cre protein. Circ Res. 2001;89(1):20-25

17. Sah $\mathrm{R}$, et al. Regulation of cardiac excitation-contraction coupling by action potential repolarization: role of the transient outward potassium current (I(to)). J Physiol. 2003;546(pt 1):5-18.

18. Day SM, et al. Histidine button engineered into cardiac troponin I protects the ischemic and failing heart. Nat Med. 2006;12(2):181-189.

19. Ringrose L, Paro R. Polycomb/Trithorax response elements and epigenetic memory of cell identity. Development. 2007;134(2):223-232

20. Glaser S, et al. Multiple epigenetic maintenance factors implicated by the loss of Mll2 in mouse development. Development. 2006;133(8):1423-1432.

21. Yu BD, Hess JL, Horning SE, Brown GA, Korsmeyer SJ. Altered Hox expression and segmental identity in Mll-mutant mice. Nature. 1995;378(6556):505-508.

22. Krivtsov AV, Armstrong SA. MLL translocations, histone modifications and leukaemia stem-cell development. Nat Rev Cancer. 2007;7(11):823-833.

23 . Varambally $S$, et al. The polycomb group protein $\mathrm{EZH} 2$ is involved in progression of prostate cancer. Nature. 2002;419(6907):624-629.

24. Terranova R, Agherbi H, Boned A, Meresse S, Djabali $\mathrm{M}$. Histone and DNA methylation defects at Hox genes in mice expressing a SET domaintruncated form of Mll. Proc Natl Acad Sci U S A. 2006;103(17):6629-6634.

25 . Lee J, et al. Targeted inactivation of MLL3 histone H3-Lys-4 methyltransferase activity in the mouse reveals vital roles for MLL3 in adipogenesis. Proc Natl Acad Sci U S A. 2008;105(49):19229-19234.

26. Cho YW, et al. Histone methylation regulator PTIP is required for PPARgamma and C/EBPalpha expression and adipogenesis. Cell Metab. 2009;10(1):27-39

27. Deschenes I, Armoundas AA, Jones SP, Tomaselli GF. Post-transcriptional gene silencing of KChIP2 and Navbeta 1 in neonatal rat cardiac myocytes reveals a functional association between $\mathrm{Na}$ and Ito currents. J Mol Cell Cardiol. 2008;45(3):336-346.

28. Fiset C, Clark RB, Larsen TS, Giles WR. A rapidly activating sustained $\mathrm{K}+$ current modulates repolarization and excitation-contraction coupling in adult mouse ventricle. J Physiol. 1997;504(pt 3):557-563.

29. Wickenden AD, Lee P, Sah R, Huang Q, Fishman GI, Backx PH. Targeted expression of a dominantnegative $\mathrm{K}(\mathrm{v}) 4.2 \mathrm{~K}(+)$ channel subunit in the mouse heart. Circ Res. 1999;85(11):1067-1076.

30. Rosati B, et al. Regulation of KChIP2 potassium channel beta subunit gene expression underlies the gradient of transient outward current in canine and human ventricle. J Physiol. 2001;533(pt 1):119-125.

31. Teutsch C, Kondo RP, Dederko DA, Chrast J, Chien KR, Giles WR. Spatial distributions of Kv4 channels and KChip2 isoforms in the murine heart based on laser capture microdissection. Cardiovasc Res. 2007;73(4):739-749.

32. Villeneuve LM, Natarajan R. The role of epigenetics in the pathology of diabetic complications. $A m J$ Physiol Renal Physiol. 2010;299(1):F14-F25.

33. Huang PH, et al. Histone deacetylase inhibitors stimulate histone $\mathrm{H} 3$ lysine 4 methylation in part via transcriptional repression of histone $\mathrm{H} 3$ lysine 4 demethylases. Mol Pharmacol. 2011;79(1):197-206.

34. Marinova Z, Leng Y, Leeds P, Chuang DM. Histone deacetylase inhibition alters histone methylation associated with heat shock protein 70 promoter modifications in astrocytes and neurons. Neuropharmacology. 2011;60(7-8):1109-1115.

35. Nightingale KP, Gendreizig S, White DA, Bradbury C, Hollfelder F, Turner BM. Cross-talk between histone modifications in response to histone deacetylase inhibitors: MLL4 links histone H3 acetylation and histone $\mathrm{H} 3 \mathrm{~K} 4$ methylation. J Biol Chem. 2007;282(7):4408-4416.

36. Palpant NJ, Day SM, Herron TJ, Converso KL, Metzger JM. Single histidine-substituted cardiac troponin I confers protection from age-related systolic and diastolic dysfunction. Cardiovasc Res. 2008;80(2):209-218.

37. Herron TJ, et al. Ca2+-independent positive molecular inotropy for failing rabbit and human cardiac muscle by alpha-myosin motor gene transfer. FASEB J. 2010;24(2):415-424.

38. Dhamoon AS, et al. Unique Kir2.x properties determine regional and species differences in the cardiac inward rectifier $\mathrm{K}+$ current. Circ Res. 2004;94(10):1332-1339.

39. Sato PY, et al. Loss of plakophilin-2 expression leads to decreased sodium current and slower conduction velocity in cultured cardiac myocytes. Circ Res. 2009;105(6):523-526 